\title{
学校における医薬品に関する教育の指導
}

\author{
鬼頭英明
}

\section{Guidance for Education on Medicines in School}

\author{
Hideaki Kito \\ Hyogo University of Teacher Education Graduate School of Education; \\ 942-1 Shimokume, Kato, Hyogo 673-1494, Japan.
}

(Received August 25, 2013)

\begin{abstract}
To promote the education on medicines in school, guidance is, as a rule, to be given in the health education of the Subject, "Health and Physical Education"' indicated as a curriculum standard in lower and upper secondary school, and in the health guidance, which carry out in Special Activities and Integrated Studies, etc. Guidance is mainly carried by the teacher for health and physical in health education and school nurse teacher (yogo teacher) in health guidance. In health education we have only limited school hours, and generally use the text book. Some teachers feel resistance to teach medicines because of needs on the special knowledge, however teachers should deal with medicines based on curriculum standard. School pharmacist is a member of school, and has a special knowledge for medicines, and he/she can support teachers as a provider of teaching materials, an adviser, and for a guest teacher. It is important for school pharmacist to understand the contents indicated in curriculum standard and to use glossary to be able to understand for children. In the guidance of health, it is not necessary to teach based on curriculum standard, and it can deal with advanced contents on medicines. However it is important to understand for children what are appropriate contents according to the development stage. To use the packages and instructions for medicines provided at home are good materials for children to have interest the medicines in their guidance. The objectives of education on medicines enable children to cultivate practical abilities for the maintenance and improvement of health.
\end{abstract}

Key words_-education; guidance; school

\section{はじめに}

医薬品に関する内容が中学校保健体育科保健分野 に新たに盛り込まれ平成 24 年度から指導が実施さ れていることに加え, 高等学校においては学習指導 要領保健体育科科目保健で内容の充実が図られ, 平 成 25 年度から年次進行（したがって，医薬品に関 する内容は平成 26 年度から）で実施されることと

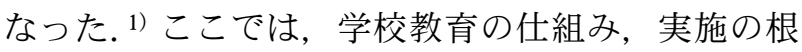
拠等について述べることとする.

\section{教育課程とは}

学校教育は, 学校教育法等で規定されており, 学 校の教育活動の基本は各学校で編成する教育課程 （カリキュラム）に基づいて実施されている，教育

The author declares no conflict of interest.

兵庫教育大学大学院学校教育研究科（干 673-1494 兵庫 県加東市下久米 942-1)

e-mail: kitohi17@hyogo-u.ac.jp

本総説は, 日本薬学会第 133 年会シンポジウム S30205 で発表した内容を中心に記述したものである.
課程は, 各校種毎に学校教育法施行規則に定められ た各教科, 道徳, 総合的な学習の時間並びに特別活 動によって編成されるものであり, 教育課程を実施 する際の基準となるのは, 文部科学大臣が公示する 学習指導要領である. 学習指導要領によって, 学習 する内容を規定する背景は, 子どもたちが全国どこ でも一定の水準の教育を受けられるようにすること を基本的な考え方としていることによるものであ る. また, 学習指導要領は, 科学技術の進歩や社会 的背景を踏まえ，およそ 10 年毎に内容が見直さ れ, 改善が図られている.

\section{学校保健とは}

学校保健とは, 学校教育法第一条に規定する学校 において幼児, 児童, 生徒, 学生並びに職員の学校 での健康に係わる領域のことをいい，保健教育と保 健管理で構成されている. ${ }^{2}$ 保健教育は，さらに保 健学習と保健指導に分けて指導が行われている. ${ }^{3)}$

文部科学省中央教育審議会健やかな体を育む教育 
の在り方に関する専門部会これまでの審議状況（平 成 17 年 7 月) 4) では, 学習指導要領の改訂に向け, 子どもたちが身に付けるべきミニマムとは何かとい う視点で議論がすすめられた。

整理された 4 つの視点のなかで，1つは親になる ための準備教育として何が必要なのかという視点, 1 つは知識を行動に結びつける力を育成していくと いう視点が重要であること，すなわち保健の分野で は，習得した科学的知識を行動に結びつけ，自他の 健康を管理し，改善するための意志決定や行動選択 につなげる実践力をすべての子どもたちに身に付け させることが重要であると指摘された.

\section{医薬品に関する保健学習}

保健学習は, 教科である体育科保健領域（小学 校), 保健体育科保健分野 (中学校), 保健体育科科 目保健（高等学校）で，それぞれの学習指導要領及 びその解説を踏まえて指導が進められる，保健学習 をすすめるに当たつての基本的な考え方は，原理・ 原則の習得を基本とするものであり，基礎的・基本 的な知識の普及と思考力, 判断力等をバランスよく 育てることを目的とする.

保健に割り当てられている時間数は，小学校 3 , 4 年の 2 学年で 8 単位時間, 5,6 年の 2 学年で 16 単位時間程度, 中学校では保健分野として 3 学年を 通じて 48 単位時間，高等学校では原則として入学 年次及びその次の年次の 2 力年とされている. ${ }^{11}$

前述した文部科学省中央教育審議会健やかな体を 育む教育の在り方に関する専門部会これまでの審議 状況（平成 17 年 7 月）では，子どもたちが身に付 けるべきミニマムの 1 つとして「医薬品の有効性や 副作用を理解し，正しく医薬品を使うことができ る」が示された. ${ }^{4)}$

新しい学習指導要領中学校保健体育科保健分野 5 ) では次のように改訂されている.

「健康な生活と疾病の予防」の中で，「健康の保持 増進や疾病の予防には，保健・医療機関を有効に利 用することがあること．また，医薬品は，正しく使 用すること」が指導内容として規定されており，学 習指導要領を具体的に解説した「学習指導要領解説」 では,「地域には，人々の健康の保持増進や疾病予 防の役割を担っている保健所，保健センター，医療 機関などがあることを理解できるようにする．健康 の保持増進と疾病の予防には，各機関がもつ機能を
有効に利用する必要があることを理解できるように する．また，医薬品には，主作用と副作用があるこ とを理解できるようにする，医薬品には，使用回 数，使用時間，使用量などの使用法があり，正しく 使用する必要があることについて理解できるように する」と示されている.

また, 学習指導要領高等学校保健体育科科目保 健6)では，「保健・医療制度及び地域の保健・医療 機関」の中で，「生涯を通じて健康の保持増進をす るには，保健・医療制度や地域の保健所，保健セン ター，医療機関などを適切に活用することが重要で あること．また，医薬品は，有効性や安全性が審査 されており，販売には制限があること，疾病からの 回復や悪化の防止には，医薬品を正しく使用するこ とが有効であること」が指導内容として規定されて おり，その解説では，「医薬品には，医療用医薬品 と一般用医薬品があること．承認制度により有効性 や安全性が審査されていること，及び販売に規制が あることを理解できるようにする，疾病からの回復 や悪化の防止には，個々の医薬品の特性を理解した 上で使用法に関する注意を守り，正しく使うことが 必要であることを理解できるようにする，その際， 副作用については，予期できるものと，予期するこ とが困難なものがあることにも触れるようにする」 が指導内容として示されている.

体育科, 保健体育科での指導については, 子ども たちにどのような力が身に付いたのか，学習評価を することが求められる．具体的には，3 観点による 評価規準（関心 - 意欲・態度，知識・理解，思考・ 判断）により個々の児童・生徒の習得状況を評価す ることとなっている.7)

以下に医薬品に関する指導を行った場合の評価の 一例を示す。

(1) 関心 ・意欲・態度 : 医薬品の有効利用につい て，健康に関する資料を見たり，自分たちの生活を 振り返つたりするなどの学習活動に意欲的に取り組

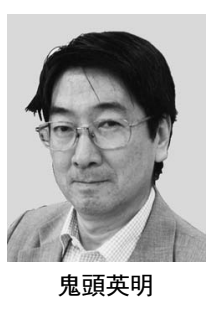

岐阜薬科大学製造薬学科卒業. 同大学 院薬学研究科修士課程修了, 同博士後 期課程単位習得退学, 岐阜薬科大学助 手，助教授を経て 1998 年文部科学省体 育局教科調査官. 2001 年スポーツ青少 年局学校健康教育課健康教育調査官. 2007 年兵庫教育大学大学院教授, 現在 に至る。 
もうとしている. 医薬品の有効利用について, 課題 の解決に向けての話し合いや意見交換などの学習活 動に意欲的に取り組もうとしている.

(2) 思考・判断：医薬品の有効利用について，学 習したことを自分たちの生活や事例などと比較した り関係を見付けたりするなどして，筋道を立ててそ れらを説明している。

（3）知識・理解：医薬品には，主作用と副作用が あること，使用回数，使用時間，使用量などの使用 法があり，正しく使用する必要があることについ て，書き出している.

指導のポイントとして求められることは，すべて の子どもたちが理解できるよう, 学習指導要領に示 された教えるべき内容を，発達段階に応じた言葉で 指導することであり，少なくとも小・中・高等学校 では，医薬品の指導をする場合であっても，薬学領 域で当たり前に使用される専門的な薬学用語を駆使 することは子どもたちにとって適切とは言えな (. ${ }^{8)}$

\section{医薬品に関する保健指導}

保健指導は特別活動や総合的な学習の時間など, 教科以外の時間を活用し，実践的なアプローチで指 導するものであり，学級担任や養護教諭などの教員 が担当することが多い。いずれにしても医薬品に関 する指導は機会を捉え，教科と連携して指導するこ とが求められる. 子どもたちが保健学習で学んだこ とをより実践的に活用できるよう指導することが求 められる。

学習指導要領総則9)では, 教育課程編成の一般方 針に「学校における体育・健康に関する指導」とし て「生徒の発達段階を考慮して，学校の教育活動全 体を通じて適切に行うものとする」とされ，具体的 には，「心身の健康の保持増進に関する指導につい ては，保健体育科の時間はもとより，技術・家庭 科，特別活動などにおいてもそれぞれの特質に応じ て適切に行うよう努めることとする。 また，それら の指導を通して，家庭や地域社会との連携を図りな がら，日常生活において適切な体育・健康に関する 活動の実践を促し，生涯を通じて健康・安全で活力 ある生活を送るための基礎が培われるよう配慮しな ければならない」と示されている.

特別活動には, 「学級活動」や「学校行事」が含 まれる。10)学級活動は「望ましい人間関係を形成
し，集団の一員として学級や学校におけるよりよい 生活づくりに参画し，諸問題を解決しようとする自 主的，実践的な態度や健全な生活態度を育てる」こ とを目的として行われる活動であり，医薬品に関す る指導については，具体的な項目として示されてい る「心身ともに健康で安全な生活態度や習慣の形成 に該当すると考えられる。「学校行事」については, 「健康安全・体育的行事」の中で「心身の健全な発 達や健康の保持増進などについての理解を深め（以 下省略)」の文言を捉えて指導することが可能と考 えられる，なお，特別活動については，各学年 35 時間が与えられている.

一方，総合的な学習の時間は，その目標を「横断 的・総合的な学習や探究的な学習を通して, 自ら課 題を見付け，自ら学び，自ら考え，主体的に判断 し，よりょく問題を解決する資質や能力を育成する とともに，学び方やものの考え方を身に付け，問題 の解決や探究活動に主体的，創造的，協同的に取り 組む態度を育て，自己の生き方を考えることができ るようにする」としている. ${ }^{11)}$

学習活動は, 学校の実態に応じて, 例えば国際理 解，情報，環境，福祉・健康などの横断的・総合的 な課題についての学習活動, 生徒の興味・関心に基 づく課題についての学習活動, 地域や学校の特色に 応じた課題についての学習活動, 職業や自己の将来 に関する学習活動などを行うこととしており，各教 科，道徳及び特別活動で身に付けた知識や技能等を 相互に関連付け，学習や生活において生かし，それ らが総合的に㗢くようにすることとしている. ${ }^{11)}$

具体的な活動の進め方については,

・グループ学習や異年齢集団による学習などの多 様な学習形態, 地域の人々の協力も得つつ全教師が 一体となって指導に当たるなどの指導体制について 工夫を行うこと.

- 学校図書館の活用，他の学校との連携，公民 館，図書館，博物館等の社会教育施設や社会教育関 係団体等の各種団体との連携，地域の教材や学習環 境の積極的な活用などの工夫を行うこと.

・職業や自己の将来に関する学習を行う際には, 問題の解決や探究活動に取り組むことを通して，自 己を理解し，将来の生き方を考えるなどの学習活動 が行われるようにすること.

などが示されており, ${ }^{6}$ キャリア教育にも結びつ 
くことから, 将来, 薬剤師となる進路選択にも発展 できる可能性もある.

\section{保健に関する指導の実施者}

指導の担当教員は, 保健学習では教育職員免許法 により各相当の免許状を有する者，すなわち小学校 では小学校教員免許状を有する教員, 中・高等学校 では保健，保健体育の免許を有する保健体育科教諭 及び兼職発令を受けた養護教諭が担当できる。一 方，保健指導については，前述したように小学校で は学級担任又は養護教諭が行う場合が多いが，小・ 中・高等学校を通じて養護教諭が中心となって指導 する場面が多くみられる.

平成 24 年度から実施されている学習指導要領に おいて，医薬品に関する内容が中学校に盛り込まれ たことで, 学校薬剤師への期待も高まっており, 学 校薬剤師がゲストティーチャー (GT)，ティームテ イーチング（T.T.）の一員として教壇に立つ機会 が増えたことに留意する必要がある。学校薬剤師 は, 学校医, 学校歯科医とともに学校三師を構成し ており, 学校保健安全法第 9 条に規定する保健指導 に従事することが求められる.

また, 学校保健安全法施行規則第 24 条に学校薬 剤師職務執行の準則が規定されており，こうした法 律に基づき, 非常勤職員としてその職能を生かし, 学校現場の教員を積極的に支援することが求められ ている.

学校薬剤師は医薬品の専門家であることから，医 薬品に関する資料提供, 指導助言, ゲストティーチ ヤーとしてサポートする場合も考えられる。学校薬 剤師は, 指導に当たつて, 学習指導要領に示された 内容を十分に理解した上で, 発達段階に応じた用語 を使うよう配慮することが求められる。保健指導に ついては, 学習指導要領に基づく必要はなく, 発展 的な内容を指導することも可能であるが，配慮すべ きことは発達段階に応じた内容とは何か, わかり易 く指導するとはどのようなことかを教員と事前に共 通理解を図っておくことである.

\section{教材の工夫}

実際の学校現場では教材として教科書が用いられ る. 教員はその内容に応じて指導案を作成し指導す ることとなる。教科書とは, 教科書の発行に関する 臨時措置法第 2 条に基づき，小学校，中学校，高等 学校，中等教育学校及びこれらに準ずる学校におい
て, 教育課程の構成に応じて組織排列された教科の 主たる教材として，教授の用に供せられる児童又は 生徒用図書であって, 文部科学大臣の検定を経たも の又は文部科学省が著作の名義を有するものとして 提供されるものである。言うまでもなく，教科書の 内容は学習指導要領及びその解説に準拠している が，発展的な内容についてはコラム欄などで取り扱 われている，教員にとっては，医薬品に関する内容 は専門的な内容も含まれることから指導することに 対して抵抗感を持つ可能性も予想されるが, 指導し ないことは許されるものではない.

このように，学校現場では主たる教材は教科書で あるが，教科書をサポートするような副教材や工夫 を凝らした教材の活用も効果的である. 保健学習, 保健指導のいずれの指導場面においても医薬品の空 箱や説明書を活用することは，家庭で身近に存在す るものであるがゆえに子どもたちにとって興味関心 を引きつける教材となり得る。具体的には，空箱や 説明書に書かれているまとまりのある項目を書き出 す教育実践例がある。 ${ }^{12)}$ (公財) 日本学校保健会は, 中学生向けのパンフレット「薬の正しい使い方」, ${ }^{13)}$ 高校生向けのパンフレット「医薬品と健康」, ${ }^{14)}$ 及 びそれぞれのパンフレットの指導者用解説 15,16$)$ を作 成し，それぞれの校種に配布してきた。学校薬剤師 が参画する場合には, 薬の原料となる植物, 実際の サンプル，視覚に訴えるわかり易い実験なども効果 的と考えられる.

\section{REFERENCES}

1) Ordinance for Enforcement of the School Education Act, 2008.

2) Act for Establishment of the Ministry of Education, Culture, Sports, Science and Technology, 2012.

3) Guidance for Health Director in School, Japanese Society of School Health, 2003.

4) The Central Council for Education, Ministry of Education, Culture, Sports, Science and Technology: 〈http://www.mext.go.jp/b_menu /shingi/chukyo/chukyo0/toushin/05091401. htm $\rangle$, cited October 8, 2013.

5) Health and Physical Education, Course of Study, Lower Secondary School, Ministry of Education, Culture, Sports, Science and Tech- 
nology (MEXT), 2008.

6) Health and Physical Education, Course of Study, Upper Secondary School, Ministry of Education, Culture, Sports, Science and Technology (MEXT), 2009.

7) Reference Material for How to Evaluate and Improvement of Evaluation Criterion of Students, National Institute for Educational Policy Research, 2010.

8) How to Think and Promote on Education of Medicines, Japanese Society of School Health, 2011.

9) General Provisions of Course of Study, Ministry of Education, Culture, Sports, Science and Technology (MEXT), 2008.

10) Special Activities of Couse of Study, Ministry of Education, Culture, Sports, Science and Technology (MEXT), 2008.
11) The Period of Integrated Studies of Course of Study, Ministry of Education, Culture, Sports, Science and Technology (MEXT), 2008.

12) Tomioka G., Ueda Y., Kito H., Nishioka N., J. Studies on Educational Practices, 13, 21-30 (2012).

13) Japanese Society of School Health: 〈http:// www.hokenkai.or.jp/iyakuhin/02.pdf $\rangle$, cited October 8, 2013.

14) Japanese Society of School Health: 〈http:// www.hokenkai.or.jp/iyakuhin/03.pdf $\rangle$, cited October 8, 2013.

15) Japanese Society of School Health: 〈http:// www.hokenkai.or.jp/iyakuhin/04-1.pdf , cited October 8, 2013

16) Japanese Society of School Health: 〈http:// www.hokenkai.or.jp/iyakuhin/05.pdf $\rangle$, cited October 8, 2013 